\title{
Field measurement of gas permeability of compacted loess used as an earthen final cover for a municipal solid waste landfill"
}

\author{
Liang-tong ZHAN ${ }^{\dagger}$, Qing-wen QIU, Wen-jie XU, Yun-min CHEN \\ (MOE Key Laboratory of Soft Soils and Geoenvironmental Engineering, Zhejiang University, Hangzhou 310058, China) \\ †E-mail: zhanlt@zju.edu.cn \\ Received Mar. 15, 2016; Revision accepted June 8, 2016; Crosschecked June 16, 2016
}

\begin{abstract}
The use of loess as an earthen final cover material is promising in northwest China which has an arid and semi-arid climate. A full-scale testing facility with an area $30 \mathrm{~m}$ long by $20 \mathrm{~m}$ wide was constructed at the Xi'an landfill of municipal solid wastes to investigate the performance of an inclined capillary barrier cover. The cover consisted of a compacted loess layer underlain by a gravel layer. The testing facility was well instrumented for a gas permeation test and recording of the soil conditions in terms of volumetric water content, pore gas pressure, and soil temperature. Tests were performed to measure the gas permeability of the compacted loess before and after the planting of vegetation on the cover. The field measurements demonstrate that the capillary break at the fine/coarse soil interface allows the upper compacted loess layer to retain more water, and conversely reduces its gas permeability, which is favorable for reducing landfill gas emissions. When the degree of saturation of the compacted loess was greater than $85 \%$, the gas permeability decreased significantly with a further increment in volumetric water content. The growth of vegetation roots tended to fill the large pores in the upper loosely-compacted loess, resulting in a decrease in gas permeability of one order of magnitude. The influence of soil clods in the compacted loess on gas permeability can be one to two orders of magnitude due to an increase in pore size and a decrease in tortuosity.
\end{abstract}

Key words: Compacted loess, Capillary barrier cover, Gas permeability, Volumetric water content, Landfill http://dx.doi.org/10.1631/jzus.A1600245

CLC number: TU43

\section{Introduction}

Earthen final covers (EFCs), as a barrier between municipal solid waste (MSW) landfill and the atmosphere, are increasingly being used to reduce deep percolation of water (Scanlon et al., 2005). EFCs work like a sponge: they store water on rainy days, and release water by evaporation and plant transpiration on sunny days. Deep percolation takes place only if the water storage is greater than the storage capacity. Two types of EFCs are commonly used, a monolithic cover (MC) with one layer of fine-grained soil,

\footnotetext{
* Project supported by the National Basic Research Program (973 Program) of China (No. 2012CB719805)

(10) ORCID: Liang-tong ZHAN, http://orcid.org/0000-0002-4483-6737; Qing-wen QIU, http://orcid.org/0000-0001-9296-391X (C) Zhejiang University and Springer-Verlag Berlin Heidelberg 2016
}

and a capillary barrier cover $(\mathrm{CBC})$ with a finegrained soil layer underlain by a coarse-grained soil layer (e.g., gravel) (Bolen et al., 2001). The difference in the unsaturated hydraulic properties of the two layers can form a capillary break at the interface. This allows the upper fine grained layer to retain more water, increasing the water storage capacity from the field capacity to a level corresponding to the water entry value of the coarse soil layer (approximately equal to the saturated volumetric water content) (Bolen et al., 2001; Albright et al., 2004). Since the 1990 s, there have been many theoretical and experimental studies on the hydrological performance of EFCs (Khire et al., 1997; Albright and Glendon, 2002; Albright et al., 2004; Benson et al., 2005; Scanlon et al., 2005; Mcguire et al., 2009; Zhang et al., 2009; Zhan et al., 2012). One of the most wellknown studies is the Alternative Cover Assessment 
Project (ACAP) organized by the Environmental Protection Agency (EPA) in the USA (Bolen et al., 2001; Albright et al., 2004). Under the ACAP, 24 full-scale lysimeter testing facilities were established at 11 landfill sites located in eight US states with different climatic conditions. The field study involved 14 EFCs, including eight MCs and six CBCs. Most of the field results demonstrated that EFCs performed well in limiting deep percolation in arid, semi-arid areas and, in some cases, semi-humid areas of the North American continent.

The biodegradation of organic waste in MSW landfills results in the production of landfill gas (LFG) that contains methane $\left(\mathrm{CH}_{4}\right)$, carbon dioxide $\left(\mathrm{CO}_{2}\right)$, and numerous other toxic compounds (Wickramarachchi et al., 2011). Uncontrolled LFG emission from MSW landfills may have a number of environmental impacts, such as increasing the greenhouse effect and surrounding air pollution. Therefore, the role of EFCs in reducing LFG emissions has recently drawn attention ( $\mathrm{Ng}$ et al., 2015; Zhan, 2015). The gas permeability of the soil materials used in EFCs is a key parameter for performance with respect to decreasing LFG emissions. Thus, further studies of their gas permeability are warranted. Wickramarachchi et al. (2011) and Hamamoto et al. (2011) carried out a series of experiments and found that for compacted silty sand used in EFCs, gas permeability decreased with increasing molding water content and compacting dry density, and increased with an increasing fraction of large particles due to an increase in pore size and a decrease in tortuosity. Maciel and Jucá $(2000 ; 2006)$ studied the influence of the degree of saturation on gas permeability of compacted clay and found a slight decrease in gas permeability with an increase in saturation from $10 \%$ to $85 \%$. Above $85 \%$ saturation, gas permeability significantly decreased with small water increments, which indicated that $85 \%$ saturation represents the point at which the air phase changes from a continuous to an occluded phase in the compacted clay. As described above, the capillary break at the fine/coarse soil interface allows the upper fine grained layer of CBCs to retain more water, and conversely reduces its gas permeability, which is favorable for reducing landfill gas emissions.

In the northwest of China, loess is widely distributed, and the climate is mainly arid and semi-arid. The use of loess as an EFC material is promising
(Zhan, 2015). Liu et al. (2010), Yao et al. (2012), and Zhan et al. (2014) showed that the effects of molding water content, compacting dry density, and degree of saturation on gas permeability of compacted loess were similar to the above results, and the influence of clod size on gas permeability can be up to three orders of magnitude. However, the gas permeability of compacted loess final covers has not been investigated sufficiently, and there is a lack of field measurements. Field measurements of the gas permeability are more representative, because the soil material and compacting method used in this study create conditions similar to actual field conditions.

A full-scale testing facility of an inclined $\mathrm{CBC}$, consisting of a compacted loess layer underlain by a gravel layer, was constructed at the Xi'an landfill. The gas permeability of the compacted loess was measured before and after planting vegetation on the cover to verify the favorable effect of the capillary break described earlier. Then the scale effect on gas permeability was analyzed by a comparison between field and laboratory measurements. The influence of vegetation roots on gas permeability was also investigated.

\section{Landfill site and field testing facility}

The Xi'an MSW landfill is located in the Jiang Cun loess gulch, $16 \mathrm{~km}$ east of Xi'an city. The landfill began operating in 1994 and is the only facility in Xi'an to deal with MSW including kitchen waste, plastics, fiber, lime soil, stone, metal, and glass. The landfill occupies an area of $7.34 \times 10^{5} \mathrm{~m}^{2}$ and was designed to contain 49 million $\mathrm{m}^{3} \mathrm{MSW}$. At present, the landfill is receiving MSW $6500 \mathrm{t} / \mathrm{d}$. The landfill consists of a number of filled $10 \mathrm{~m}$-high platforms that are set back on an embankment slope of $18.4^{\circ}$. An area $30 \mathrm{~m}$ long by $20 \mathrm{~m}$ wide was selected between the 7th and 8th platforms to construct the full-scale testing facility of an inclined CBC consisting of a compacted loess layer underlain by a gravel layer (Fig. 1). The construction of the facility started in December 2013. At this time, the age of the waste layer under the facility area ranged from 3 to 5 years and the landfill slope had reached a height of $90 \mathrm{~m}$. The construction of the facility was completed in May 2014 (Fig. 2). 
The full-scale testing facility of the $\mathrm{CBC}$ was constructed in a way similar to the test zones of ACAP in the USA, with the exception of the components for gas permeation tests. The main feature of all ACAP test zones was a large $(10 \mathrm{~m} \times 20 \mathrm{~m})$ instrumented pan-type lysimeter. A detailed description of the construction of each ACAP test zone can be found in Bolen et al. (2001). The lysimeter used in this study was $24 \mathrm{~m}$ long and $10 \mathrm{~m}$ wide. A $5 \mathrm{~m}$-wide buffer area was set around the perimeter of the

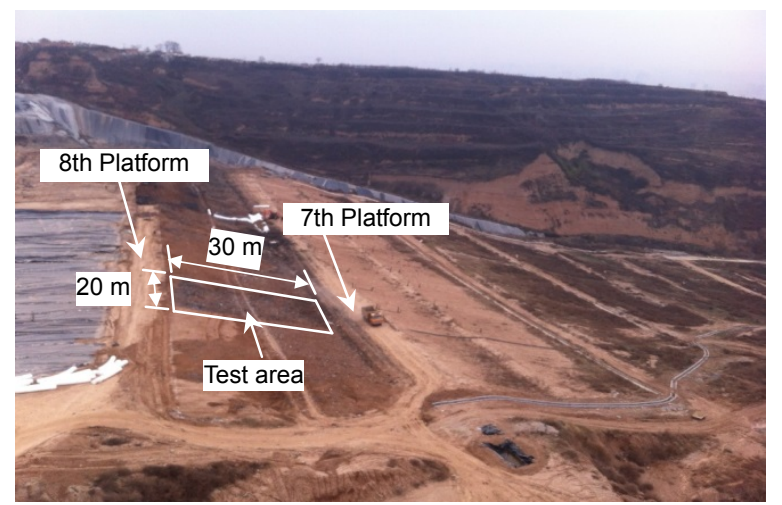

Fig. 1 Location of the full-scale testing facility

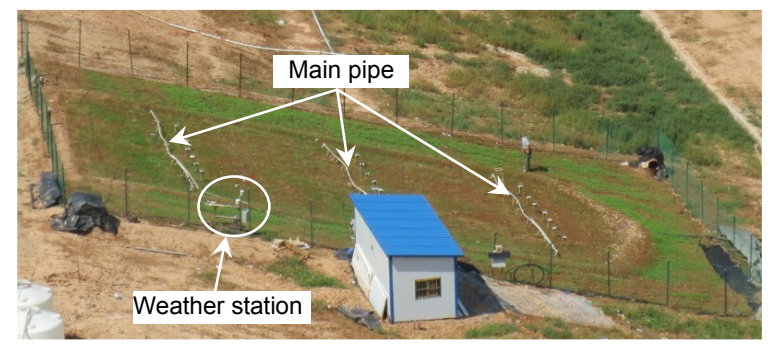

Fig. 2 Overall view of the full-scale testing facility lysimeter to reduce boundary effects (Fig. 3). The base and sidewalls of the lysimeter were lined with a high density polyethylene (HDPE) geomembrane to create an independent hydrological unit in which tests could be performed to measure the gas permeability of the compacted loess. During the gas permeation test process, the pore gas pressure at the bottom of the $\mathrm{CBC}$ could be controlled and the pore gas pressure at the surface was equal to atmospheric pressure. The profile of the $\mathrm{CBC}$ above the base geomembrane comprised a geotextile protection layer, a $0.3 \mathrm{~m}$-thick gravel layer, a geotextile separation layer and $0.9 \mathrm{~m}$ of compacted loess (Fig. 3). The compacted loess layer was subdivided into a $0.3 \mathrm{~m}$-thick top soil layer and a $0.6 \mathrm{~m}$-thick water storage layer of compacted loess $\left(\rho_{\mathrm{d}}=1.45 \mathrm{Mg} / \mathrm{m}^{3}\right)$. The top soil layer consisted of compacted loess $\left(\rho_{\mathrm{d}}=1.3 \mathrm{Mg} / \mathrm{m}^{3}\right)$ and compost soil in a ratio of 1:0.03. The gravel layer, consisting of a $0.1 \mathrm{~m}$-thick gravel layer \#1 $(0.5-1 \mathrm{~cm}$ in particle size $)$ and a $0.2 \mathrm{~m}$-thick gravel layer \#2 $(1-2 \mathrm{~cm}$ in particle size), was used as the gas distribution layer of the cover. The profile under the base geomembrane comprised a geotextile protection layer, a $0.3 \mathrm{~m}$-thick gravel layer, \#3 (3-5 cm in particle size), a geotextile separation layer, and a waste layer. Perforated polyethylene (PE) pipelines were installed in gravel layer \#3 for collection of landfill gas.

The loess material used in the $\mathrm{CBC}$ was taken from an excavated slope near the Xi'an landfill, and contained many soil clods. Layered compaction was used to construct the $\mathrm{CBC}$ using an electric shocking rammer. The interface between layers was not

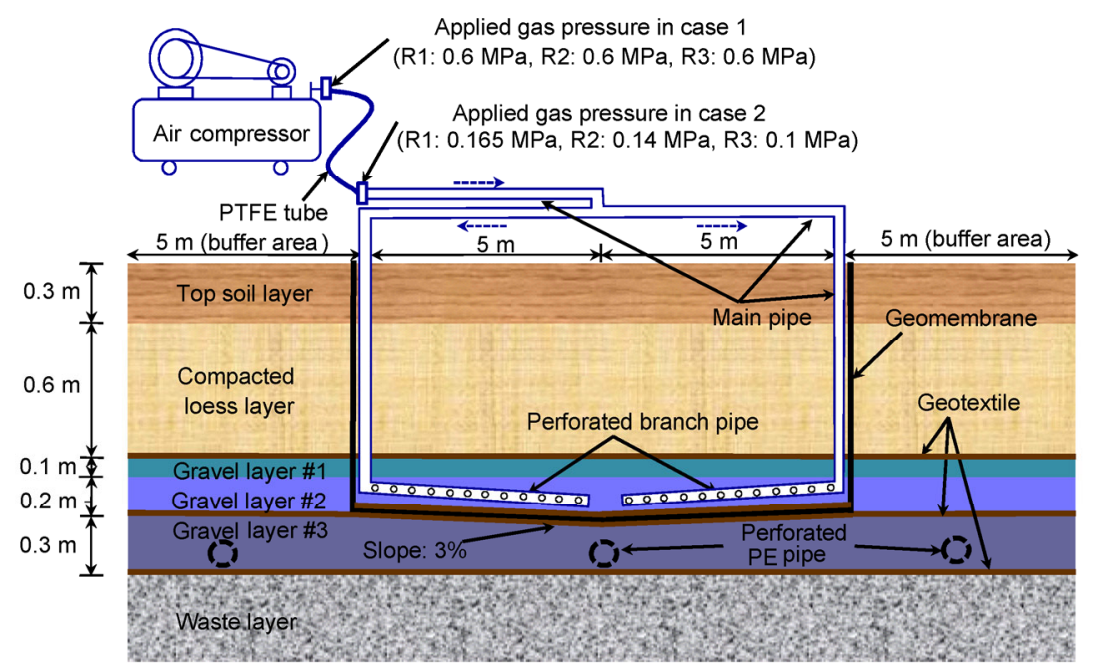

Fig. 3 Cross section of the full-scale testing facility 
scarified and thus was relatively non-uniform. The loess material and construction method used in the CBC created conditions similar to the actual field situation. Fig. 4 shows the drying and wetting soil water characteristic curves (SWCCs) of the compacted loess with dry densities of 1.3 and $1.45 \mathrm{Mg} / \mathrm{m}^{3}$. The SWCCs were fitted by the van Genuchten equation using the field data recorded during the wet season of 2014 by time domain reflectometer probes (TDRs) and jet filled tensiometers. The saturated water contents $\left(\theta_{\mathrm{s}}\right)$ of the compacted loess with dry densities of 1.3 and $1.45 \mathrm{Mg} / \mathrm{m}^{3}$ were $50 \%$ and $47 \%$, respectively. The values of field capacity $\left(\theta_{\mathrm{c}}\right)$ corresponding to a suction of $33 \mathrm{kPa}$ for the compacted loess with dry densities of 1.3 and $1.45 \mathrm{Mg} / \mathrm{m}^{3}$ were $28 \%-31 \%$ and $30 \%-34 \%$, respectively.

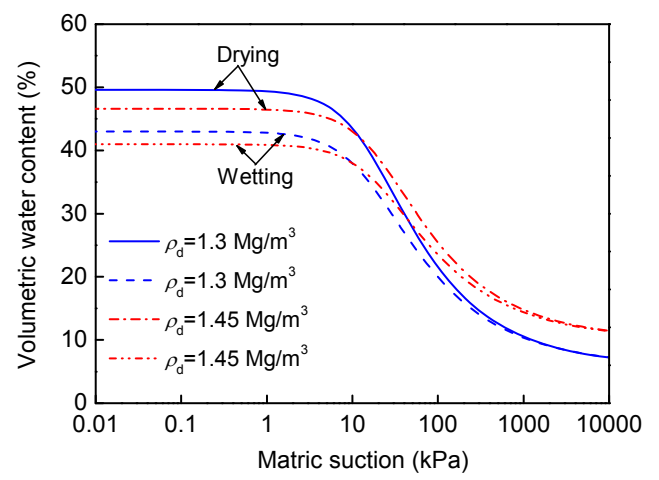

Fig. 4 Drying and wetting SWCCs of the compacted loess $\left(\rho_{\mathrm{d}}=1.3 \mathrm{Mg} / \mathrm{m}^{3}\right.$ and $\left.1.45 \mathrm{Mg} / \mathrm{m}^{3}\right)$

\section{Gas supply system and gas permeation test}

The gas supply system used in the gas permeation tests consisted of some perforated branch pipes and main pipes (Fig. 3). All the pipes were made of polypropylene (PPR). Half of the gas supply system consisted of two main pipes ( $2.5 \mathrm{~cm}$ in diameter) and four perforated branch pipes $(2 \mathrm{~cm}$ in diameter) (Fig. 5). The perforated branch pipes were installed in gravel layer \#2 and spaced $2 \mathrm{~m}$ apart along the down slope direction. One main pipe was extended to the surface to connect with the other half of the system by a main pipe (Fig. 3). There were three gas supply systems installed, one in each of the three sections of the testing facility (i.e., $\mathrm{R} 1$ in the upper part, $\mathrm{R} 2$ in the middle part, and $\mathrm{R} 3$ in the lower part of the $\mathrm{CBC}$ slope) (Fig. 6).

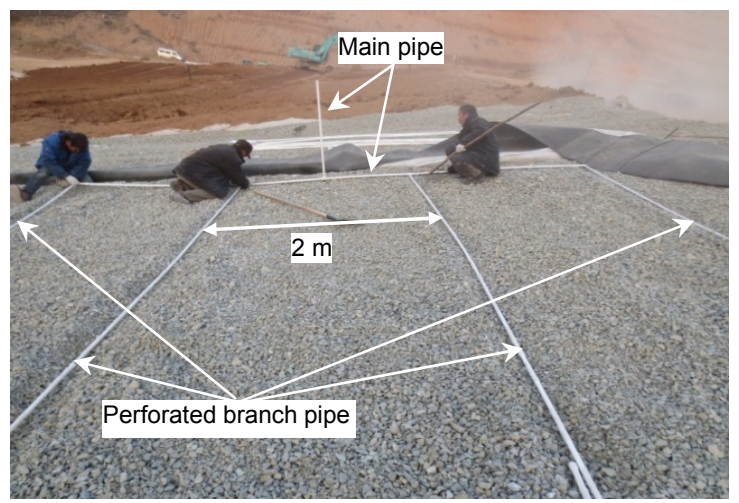

Fig. 5 Half part of the gas supply system

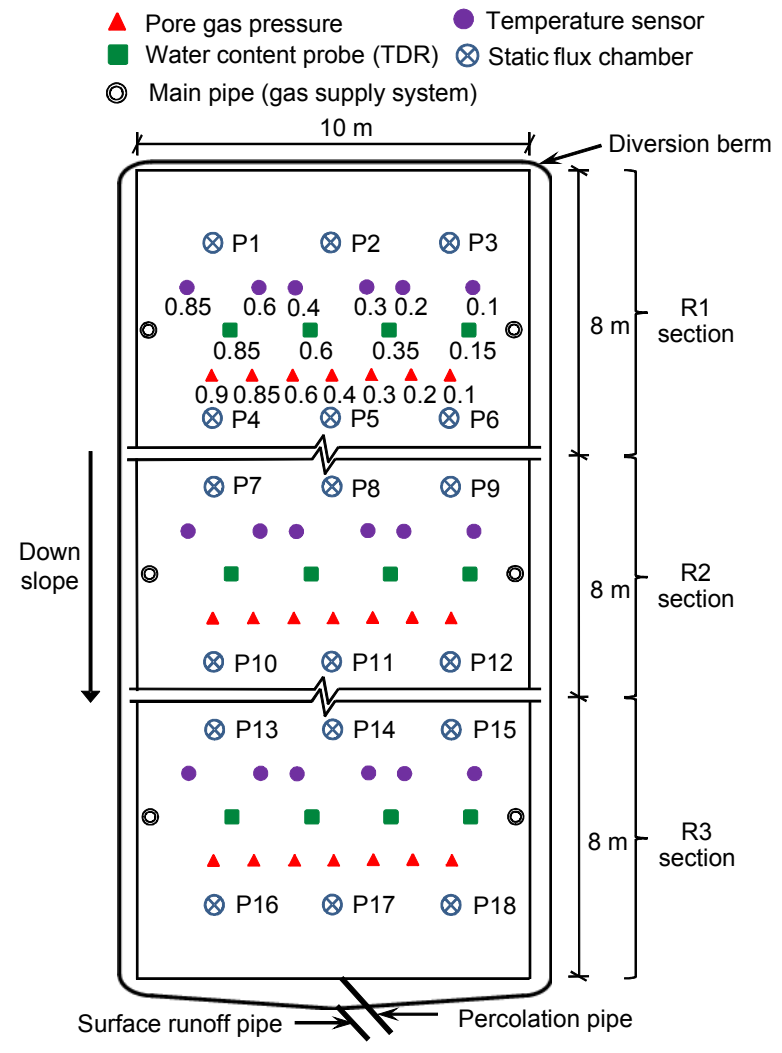

Fig. 6 Layout of instrumentation

To eliminate the technical difficulties in working with LFG consisting of many kinds of gas as described earlier, gas permeation tests were performed by pumping compacted air, as the permeating fluid, into gravel layer \#2 via the three gas supply systems of each of the three sections. An air compressor was connected with the three gas supply systems by three polytetrafluoroethylene (PTFE) tubes $(1 \mathrm{~cm}$ in diameter) 18,25 , and $34 \mathrm{~m}$ long for the R1, R2, and R3 
sections, respectively. Three inline pressure regulators were used to control the gas pressure in the three PTFE tubes or the three main pipes at the cover surface, in order to control the pore gas pressures at the bottom of the three sections of the CBC (Fig. 3). In the gas distribution layer, the gas pressures under the compacted loess layer for the three sections could be very similar. We assumed that gas migration in the compacted loess layer was $1 \mathrm{D}$, because the $0.9 \mathrm{~m}$ thickness of the compacted loess layer is far less than that of each $8 \mathrm{~m}$ long and $10 \mathrm{~m}$ wide section and this study focused only on the overall gas permeability of the three sections of the CBC.

Two gas permeation tests were performed (Table 1). The first test (case 1) was conducted on July 16,2014 when no vegetation was planted on the CBC surface. The three pressure regulators were used to control the gas pressure into the three PTFE tubes at 0.6 MPa (Fig. 3). After case 1, the CBC was planted with a mixture of Ilex purpurea Hassk, ryegrass, and bluegrass in a ratio of 4:3:3 in July 2014. On Dec. 28, 2014, the second test (case 2) was performed, and the three pressure regulators were used to control the gas pressure into the three main pipes at the cover surface at $0.165,0.14$, and $0.1 \mathrm{MPa}$, respectively (Fig. 3). Note that the two gas permeation tests were performed after simulating extreme rainfall and a subsequent period of drying (evapotranspiration), in order to measure the gas permeability of the compacted loess with high water content.

Table 1 Testing program

\begin{tabular}{clccc}
\hline \multirow{2}{*}{ Case } & Vegetation type & \multicolumn{3}{c}{$\begin{array}{c}\text { Applied gas pressure into PTFE } \\
\text { tubes (for case 1) and main pipes } \\
\text { (for case 2) (MPa) }\end{array}$} \\
\cline { 2 - 5 } & $\mathrm{R} 1$ & $\mathrm{R} 2$ & $\mathrm{R} 3$ \\
\hline $1 \quad$ No vegetation & 0.6 & 0.6 & 0.6 \\
2 & $\begin{array}{l}\text { Mixture of Ilex } \\
\text { purpurea Hassk, } \\
\text { ryegrass, and } \\
\text { bluegrass }\end{array}$ & 0.165 & 0.14 & 0.1 \\
\hline
\end{tabular}

\section{Layout of instrumentation}

Instruments were installed at the $\mathrm{CBC}$ to continuously monitor soil conditions (volumetric water content, temperature, and pore gas pressure) and meteorological conditions. The three sections were equipped with the same instruments (Fig. 6). These instruments were installed during the construction process of the $\mathrm{CBC}$ testing facility.

The pore gas pressure at seven depths from 0.1 to $0.9 \mathrm{~m}$ for each section, was measured using a pressure meter (DPGM409-350HCG, OMEGA Engineering, Inc., USA) connected to a gravel bag $(10 \mathrm{~cm}$ in diameter $)$ installed at the desired depth by a PTFE tube $(0.6 \mathrm{~cm}$ in diameter). The gravel bags in each section were spaced $1 \mathrm{~m}$ apart along the horizontal direction (Fig. 6).

The volumetric water content of the four depths from 0.15 to $0.85 \mathrm{~m}$ for each section was measured using a time domain reflectometer probe (TDR). The TDRs in each section were spaced $2.5 \mathrm{~m}$ apart along the horizontal direction (Fig. 6). The TDR adopts a standing wave technique to measure the apparent dielectric constant of the compacted loess. The measured apparent dielectric constant is correlated with the volumetric water content of the compacted loess. The accuracy of the measurements is affected by many factors such as variation in soil composition, dry density, and cracks (Zhan et al., 2007). For the field monitoring reported in this paper, in situ calibrations were carried out. Results of the calibrations indicated that measurement error could be less than $2 \%$ of the volumetric water content.

The temperature of the six depths from 0.1 to $0.85 \mathrm{~m}$ for each section was measured using a temperature probe (WZPM-201, Hangzhou Tuo Sheng Automation Instrument Co., Ltd., China) connected to a data recorder. The temperature probes in each section were spaced 0.9 or $1.8 \mathrm{~m}$ apart along the horizontal direction (Fig. 6).

When the pore gas pressure at different depths for the three sections showed no change during the gas permeation tests, the tests were considered to have reached a steady state. Then the pore gas pressure, volumetric water content, and temperature profiles of the three sections were measured. The gas volume emission rate from the $\mathrm{CBC}$ into the atmosphere was measured using a static flux chamber (diameter $50 \mathrm{~cm}$, height $40 \mathrm{~cm}$ ) connected to a digital bubble flowmeter (Fig. 7). A total of 18 measuring points (i.e., $\mathrm{P} 1-\mathrm{P} 18$ ) were set on the $\mathrm{CBC}$ surface (Fig. 6). The measuring range of the digital bubble flowmeter (GL-102B, Beijing Youyi Sifang Technology Development Co., Ltd., China) was 2- 
$2000 \mathrm{ml} / \mathrm{min}$. Its measuring principle was described by Maciel and Jucá (2000). Two key points should be noted: first, the static flux chamber should be inserted in the cover surface at a depth of $0.1 \mathrm{~m}$ and some water should be sprinkled into the loess around the chamber to ensure a good seal and prevent gas from leaking; second, the flowmeter, with a bubble created artificially instead of being blown by gas from the chamber into the flowmeter, was connected to the chamber to measure the gas volume emission rate only when the gas outflow rate was equal to the inflow rate of the chamber. All this was done to ensure that the gas pressure in the chamber was equal to the atmospheric pressure, with the purpose of accurately measuring the gas volume emission rate.

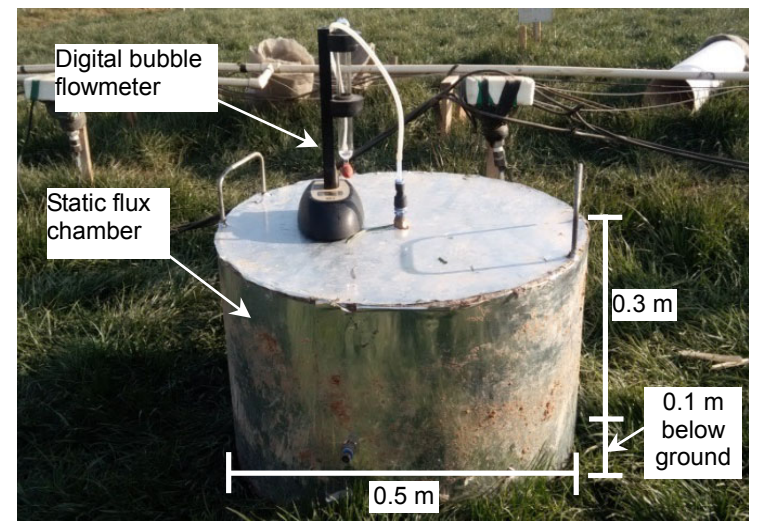

Fig. 7 Static flux chamber connected to a digital bubble flowmeter

Meteorological conditions were measured by a weather station installed near the testing facility (Fig. 2). The measurements included atmospheric pressure, atmospheric temperature, wind speed, and precipitation, all of which can have a significant impact on the gas volume emission rate. The measured gas volume emission rate can be transformed into the gas mass emission rate by using the measured atmospheric pressure and air temperature data. The measured pore gas pressure can be transformed into the absolute pore gas pressure.

\section{Calculation of gas permeability}

During the gas permeation tests, the $1 \mathrm{D}$ governing equation of gas migration in the compacted loess layer of the $\mathrm{CBC}$ is shown as

$$
\frac{\partial(\rho \theta)}{\partial t}=\frac{\partial}{\partial z}\left[\frac{\rho K_{a}}{\mu}\left(\frac{\partial p}{\partial z}-\rho g\right)\right]
$$

where $\rho$ is the gas density $\left(\mathrm{kg} / \mathrm{m}^{3}\right), \theta$ is the volumetric air content, $t$ is the time, $K_{a}$ is the gas permeability $\left(\mathrm{m}^{2}\right), \mu$ is the gas viscosity $(\mathrm{Pa} \cdot \mathrm{s}), p$ is the absolute gas pressure (Pa), $z$ is the vertical coordinate $(\mathrm{m})$, and $g$ is the acceleration of gravity $(\mathrm{N} / \mathrm{kg})$.

Air viscosity can be determined by (Wang et al., 2003)

$$
\mu=\mu_{0} \frac{273+C}{T+C}\left(\frac{T}{273}\right)^{1.5}
$$

where $\mu_{0}$ is $1.71 \times 10^{-5} \mathrm{~Pa} \cdot \mathrm{s}, T$ is the thermodynamic temperature $(\mathrm{K})$, and $C$ is $122 \mathrm{~K}$.

When the gas migration reaches a steady state, the gas mass inflow rate will be equal to the outflow rate of the compacted loess layer, and then Eq. (1) can be transformed to the following equation:

$$
\frac{\partial}{\partial z}\left[\frac{\rho K_{a}}{\mu}\left(\frac{\partial p}{\partial z}-\rho g\right)\right]=0
$$

The solution for Eq. (3) can be obtained:

$$
K_{a}=\frac{q \mu}{\rho\left(\frac{\partial p}{\partial z}-\rho g\right)} .
$$

From the ideal gas equation, the gas density can be calculated by

$$
\rho=\frac{p w}{R T}
$$

where $w$ is the molar mass of air $(0.029 \mathrm{~kg} / \mathrm{mol})$, and $R$ is the ideal gas constant $(8.314 \mathrm{~J} /(\mathrm{mol} \cdot \mathrm{K}))$.

Substituting Eq. (5) into Eq. (4), we can obtain:

$$
K_{a}=\frac{q \mu}{\frac{w}{2 R T} \frac{\partial p^{2}}{\partial z}-\left(\frac{p w}{R T}\right)^{2} g},
$$

where $q$ is the gas mass flow rate through the small segment $\left(\mathrm{kg} /\left(\mathrm{m}^{2} \cdot \mathrm{s}\right)\right)$. 
Note that the compacted loess layer was subdivided into some small segments according to the distribution of the gas pressure measuring points. The absolute bottom and upper gas pressures of a small segment can be obtained as $p_{\mathrm{b}}$ and $p_{\mathrm{u}}$. Eq. (6) can be transformed into the following equation:

$$
K_{a}=\frac{q \mu}{\frac{w}{2 R T} \frac{p_{\mathrm{b}}^{2}-p_{\mathrm{u}}^{2}}{L}-\left[\frac{\left(p_{\mathrm{b}}+p_{\mathrm{u}}\right) w}{2 R T}\right]^{2} g},
$$

where $L$ is the thickness of the small segment (m).

Taking Fig. 8a as an example, the pore gas pressures on both ends of five small segments of the three sections were obtained for case 1 . The depth scopes of the five small segments were $0-0.3,0.3-0.4$, $0.4-0.6,0.6-0.85$, and $0.85-0.9 \mathrm{~m}$, respectively. The pore gas pressure at $0 \mathrm{~m}$ depth was atmospheric pressure. The dry density of the first small segment with the depth scope of $0-0.3 \mathrm{~m}$ was $1.3 \mathrm{Mg} / \mathrm{m}^{3}$, and the dry density of the other four small segments was $1.45 \mathrm{Mg} / \mathrm{m}^{3}$. The average temperature and volumetric water content of each small segment were obtained by an interpolation method using the measured temperature profiles and volumetric water content profiles. The gas mass flow rate of a small segment was determined as the average gas mass emission rate
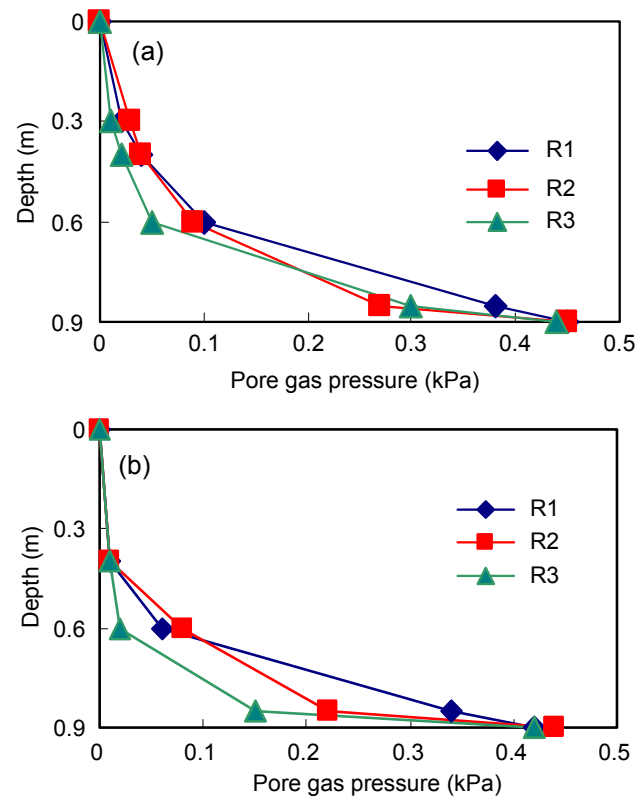

Fig. 8 Gas pressure profiles of the three sections: (a) case 1; (b) case 2 of the section to which the small segment belonged. The average gas mass emission rate was calculated as the average value of the six measuring points of the section.

\section{Results and discussion}

When the two gas permeation tests reached a steady state, the profiles of the pore gas pressure, volumetric water content, and temperature of the three sections could be obtained. Fig. 8 shows that the pore gas pressures at a depth of $0.9 \mathrm{~m}$ of the three sections for the two cases were very similar, which confirms the diffusion function of the gas distribution layer. The largest differences in magnitude of the pore gas pressure were at a depth of $0.85 \mathrm{~m}$ for the three sections. The differences were 0.11 and $0.19 \mathrm{kPa}$ for the two cases, respectively. Fig. 9 shows that the volumetric water contents at a depth of $0.85 \mathrm{~m}$ for the three sections were close to the saturated volumetric water content (i.e., 47\%). The gas permeability at that depth will reduce or increase significantly with a slight change in the volumetric water content, which will cause a big difference in the magnitude of the pore gas pressure, as described earlier (Maciel and Jucá, 2006). Fig. 8 shows that for the three sections, the pore gas pressure reduced more quickly at a depth
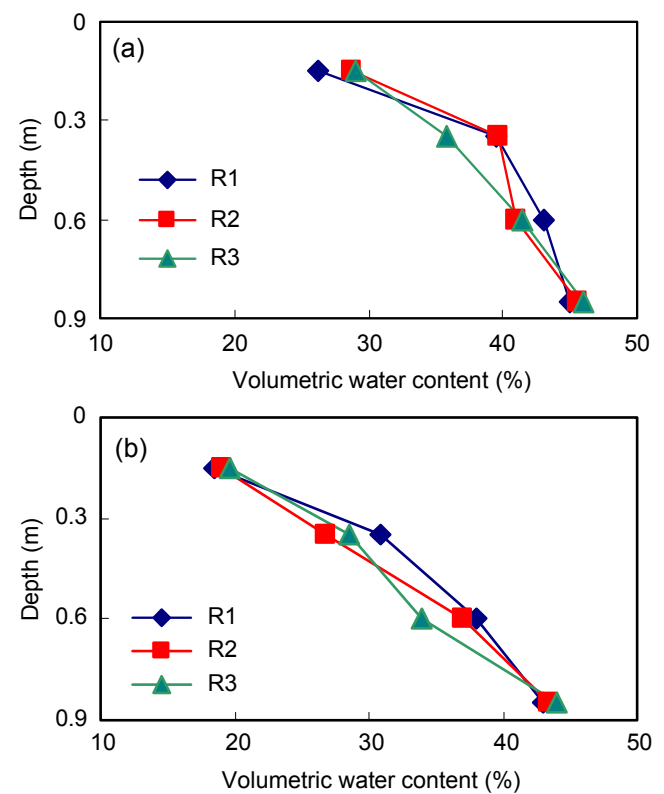

Fig. 9 Volumetric water content profiles of the three sections: (a) case 1 ; (b) case 2 
of between 0.6 and $0.9 \mathrm{~m}$ than at a depth of between 0 and $0.6 \mathrm{~m}$. This is because the gas permeability at the greater depth was lower due to the volumetric water content being higher.

Fig. 9 shows that the volumetric water content decreases from the deepest to the shallowest of the three sections. This is because the two cases were both performed after simulating extreme rainfall and a subsequent period of drying (evapotranspiration).

Fig. 10 shows that for the three sections, the temperature decreased from the deep to the shallow sections. This is because a deep section is closer to the waste layer which generates heat by biochemical degradation. The temperature in case 1 was greater than in case 2 . This is because case 1 was carried out in summer and case 2 in winter.
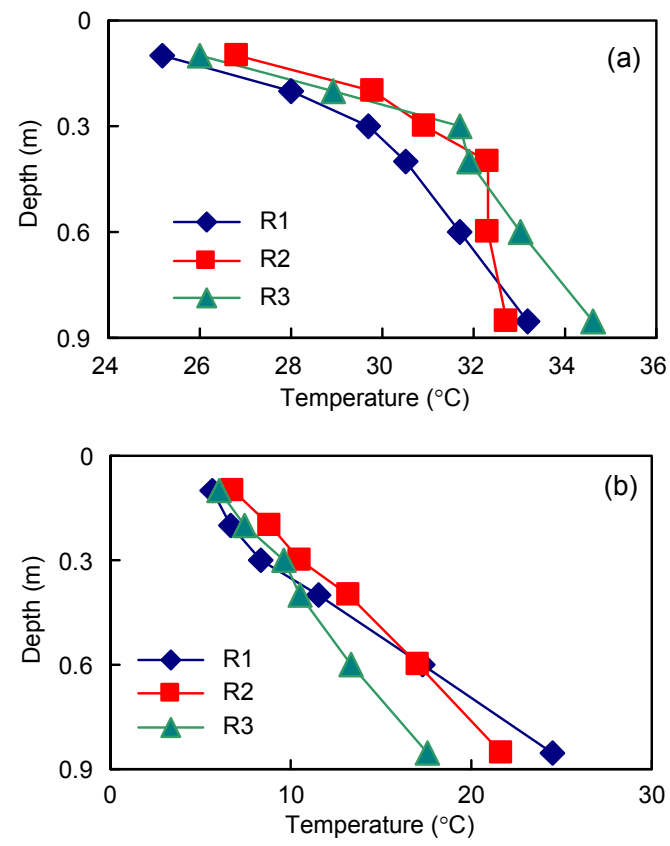

Fig. 10 Temperature profiles of the three sections: (a) case 1 ; (b) case 2

Meteorological conditions, including atmospheric pressure, atmospheric temperature, and wind speed during the two cases, are shown in Table 2 . Note that the weather was sunny for both cases. The wind speed for the two cases was low, so atmospheric pressure can be considered relatively stable.

Table 3 shows the gas mass emission rates of the 18 measuring points of the three sections for the two cases. The mean value and standard deviation of the 18 gas mass emission rates for case 1 were $1.43 \times 10^{-5}$ and $5.31 \times 10^{-6} \mathrm{~kg} /\left(\mathrm{m}^{2} \cdot \mathrm{s}\right)$, respectively. The standard deviation was only 0.37 times the mean value, so spatial variability can be considered not large. For case 2 , the mean value and standard deviation were $4.77 \times 10^{-6}$ and $2.84 \times 10^{-6} \mathrm{~kg} /\left(\mathrm{m}^{2} \cdot \mathrm{s}\right)$, respectively. The standard deviation was 0.59 times the mean. The spatial variability of case 2 was slightly greater than that of case 1 . The average gas mass emission rates of the R1, R2, and R3 sections for case 1 were $1.21 \times 10^{-5}$, $1.18 \times 10^{-5}$, and $1.89 \times 10^{-5} \mathrm{~kg} /\left(\mathrm{m}^{2} \cdot \mathrm{s}\right)$, respectively. The results for case 2 were $4.04 \times 10^{-6}, 4.91 \times 10^{-6}$, and $5.37 \times 10^{-6} \mathrm{~kg} /\left(\mathrm{m}^{2} \cdot \mathrm{s}\right)$, respectively. The average gas

Table 2 Meteorological conditions for the two cases

\begin{tabular}{ccccc}
\hline Case & Time & $\begin{array}{c}\text { Atmospheric } \\
\text { temperature } \\
\left({ }^{\circ} \mathrm{C}\right)\end{array}$ & $\begin{array}{c}\text { Atmospheric } \\
\text { pressure } \\
(\mathrm{kPa})\end{array}$ & $\begin{array}{c}\text { Wind } \\
\text { speed } \\
(\mathrm{m} / \mathrm{s})\end{array}$ \\
\hline \multirow{3}{*}{1} & $9: 00 \mathrm{am}$ & 31.7 & 94.21 & 0.14 \\
& $10: 00 \mathrm{am}$ & 31.8 & 94.21 & 0.07 \\
& $11: 00 \mathrm{am}$ & 31.7 & 94.22 & 0.19 \\
\hline \multirow{3}{*}{2} & $3: 00 \mathrm{pm}$ & 14.5 & 95.64 & 0 \\
& $4: 00 \mathrm{pm}$ & 15.0 & 95.58 & 0 \\
& $5: 00 \mathrm{pm}$ & 12.5 & 95.57 & 0.19 \\
\hline
\end{tabular}

Table 3 Gas mass emission rates of the 18 measuring points for the two cases

\begin{tabular}{|c|c|c|c|}
\hline \multirow[t]{2}{*}{ Section } & \multirow{2}{*}{$\begin{array}{c}\text { Measured } \\
\text { point }\end{array}$} & \multicolumn{2}{|c|}{$\begin{array}{l}\text { Gas mass emission rate } \\
\left(\times 10^{-6} \mathrm{~kg} /\left(\mathrm{m}^{2} \cdot \mathrm{s}\right)\right)\end{array}$} \\
\hline & & Case 1 & Case 2 \\
\hline \multirow{6}{*}{ R1 } & P1 & 13.29 & 3.26 \\
\hline & P2 & 12.31 & 4.29 \\
\hline & P3 & 7.43 & 3.20 \\
\hline & P4 & 10.79 & 6.30 \\
\hline & P5 & 15.29 & 5.36 \\
\hline & P6 & 13.78 & 1.84 \\
\hline \multirow{6}{*}{$\mathrm{R} 2$} & P7 & 12.11 & 1.03 \\
\hline & P8 & 8.40 & 1.97 \\
\hline & P9 & 23.08 & 10.71 \\
\hline & P10 & 10.83 & 6.41 \\
\hline & P11 & 8.34 & 3.34 \\
\hline & $\mathrm{P} 12$ & 7.74 & 6.00 \\
\hline \multirow{6}{*}{ R3 } & P13 & 24.46 & 6.68 \\
\hline & P14 & 21.20 & 2.82 \\
\hline & P15 & 21.66 & 5.80 \\
\hline & P16 & 17.37 & 11.32 \\
\hline & P17 & 17.65 & 1.06 \\
\hline & P18 & 11.17 & 4.54 \\
\hline
\end{tabular}


mass emission rates of the three sections for the two cases were very similar. So the assumption described earlier, that air migration in the compacted loess layer is $1 \mathrm{D}$, is reasonable.

According to the pore gas pressure profiles, temperature profiles, volumetric water content profiles, and average gas mass emission rates of the three sections for the two cases, the gas permeability of the two compacted loess layers with dry densities of 1.45 and $1.3 \mathrm{Mg} / \mathrm{m}^{3}$ were determined and compared with laboratory measurements (Fig. 11).

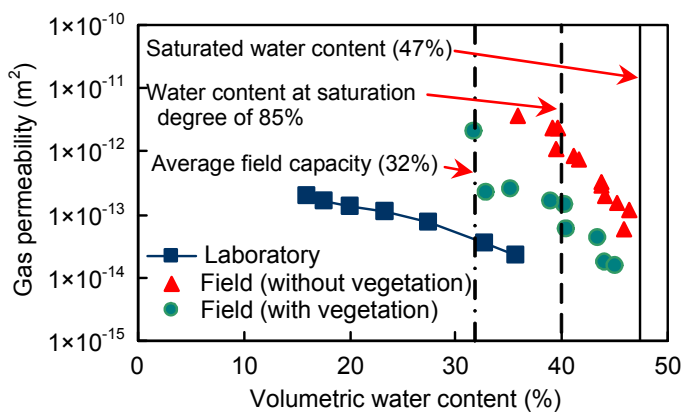

(a)

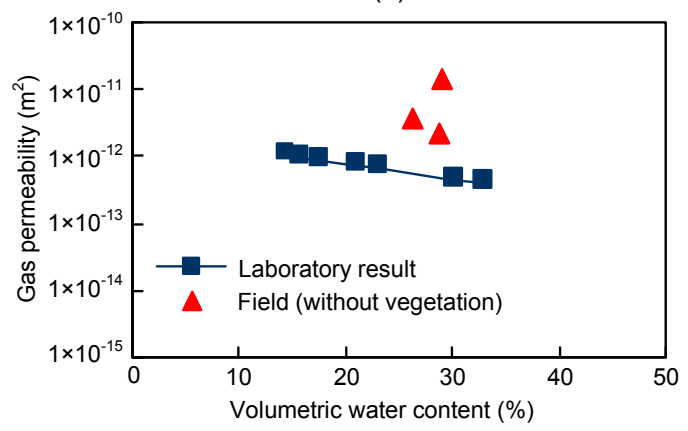

(b)

Fig. 11 Comparison of gas permeability between field and laboratory measurements: (a) $\rho_{\mathrm{d}}=1.45 \mathrm{Mg} / \mathrm{m}^{3}$; (b) $\rho_{\mathrm{d}}=$ $1.3 \mathrm{Mg} / \mathrm{m}^{3}$

Fig. 11 shows that before planting vegetation, for the compacted loess $\left(\rho_{\mathrm{d}}=1.45 \mathrm{Mg} / \mathrm{m}^{3}\right)$, field measurements of gas permeability ranged from $3.67 \times 10^{-12}$ to $5.73 \times 10^{-14} \mathrm{~m}^{2}$ when the volumetric water content changed from $36 \%$ to $46 \%$; for the compacted loess $\left(\rho_{\mathrm{d}}=1.3 \mathrm{Mg} / \mathrm{m}^{3}\right)$, the gas permeability ranged from $1.41 \times 10^{-11}$ to $2.25 \times 10^{-12} \mathrm{~m}^{2}$ when the volumetric water content changed from $26 \%$ to $29 \%$. After planting vegetation, the field measurement of the gas permeability of the compacted loess $\left(\rho_{\mathrm{d}}=1.45 \mathrm{Mg} / \mathrm{m}^{3}\right)$ ranged from $2.12 \times 10^{-12}$ to $1.57 \times 10^{-14} \mathrm{~m}^{2}$ when the volumetric water content changed from $32 \%$ to $45 \%$.
Fig. 11a shows a comparison of the gas permeability of the compacted loess $\left(\rho_{\mathrm{d}}=1.45 \mathrm{Mg} / \mathrm{m}^{3}\right)$ before and after planting vegetation. Permeability before planting was greater than that after planting by about one order of magnitude. This is because the growth of vegetation roots tends to fill the large pores of the loess, which reduces gas permeability. The large pores are a key factor affecting the gas permeability of soil (Moldrup et al., 2001). Fig. 12 shows that the denseness of vegetation roots decreases with increasing depth. Roots reached a maximum depth at below $50 \mathrm{~cm}$. Pierret et al. (1999), Kozlowski (1999), and Stewart et al. (1999) showed that vegetation roots are not evenly distributed throughout the soil and tend to grow in large pores, especially continuous large pores, in which roots can more easily access water, air, and mineral nutrients for growth.

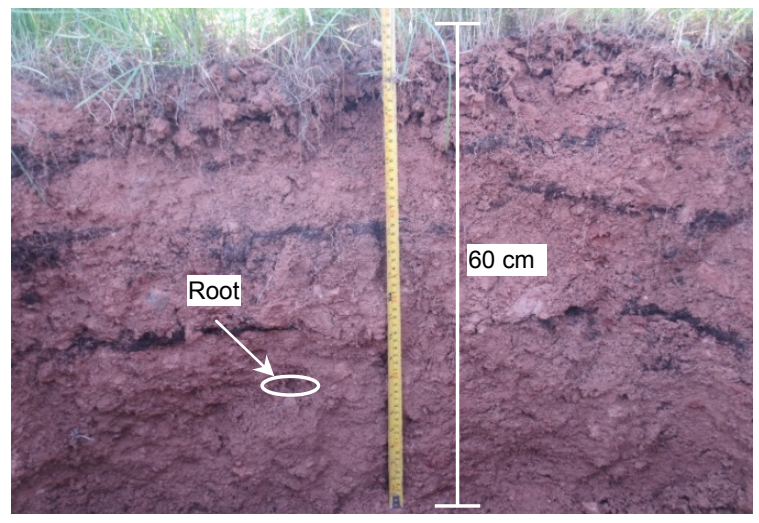

Fig. 12 Depth of distribution of vegetation roots

Fig. 11a shows that for both cases, the gas permeability of the compacted loess $\left(\rho_{\mathrm{d}}=1.45 \mathrm{Mg} / \mathrm{m}^{3}\right)$ reduced slightly with increasing volumetric water content from the average field capacity (i.e., $32 \%$ ) to $85 \%$ saturation (i.e., $40 \%$ ). However, from a volumetric water content of $40 \%$ to the saturated volumetric water content (i.e., 47\%), the gas permeability significantly decreased with small water increments. Maciel and Jucá $(2000 ; 2006)$ have also observed this behavior. So the capillary break at the loess/gravel interface allows the upper loess layer to retain more water, and conversely decreases its gas permeability, which is favorable for the $\mathrm{CBC}$ to reduce $\mathrm{LFG}$ emissions.

Fig. 11 shows that the field measurements of the gas permeability of the compacted loess with dry densities of 1.3 and $1.45 \mathrm{Mg} / \mathrm{m}^{3}$ were greater than laboratory measurements by one to two orders of 
magnitude. This is because the loess material used in the field tests was different from that used in the laboratory tests (Fig. 13). In the field tests, the loess material was natural loess with large soil clods. However, for the laboratory tests, it was obtained by natural loess being first broken up with a rubber hammer and then filtered through a $2 \mathrm{~mm}$ aperture sieve, and so contained no soil clods. Soil clods can create more continuous gas-phase pathways (i.e., decrease tortuosity) and increase pore size in soil (Moldrup et al., 2001; Zhan et al., 2014). Gas flow is more likely to take place in larger and more continuous pores (preferential gas flow effects) (Moldrup $e t$ al., 2001). So the field measurements of gas permeability of the compacted loess were greater than the laboratory measurements.

(a)

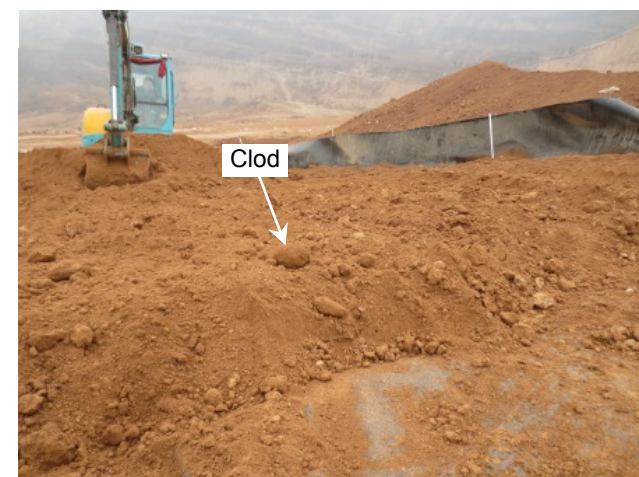

(b)

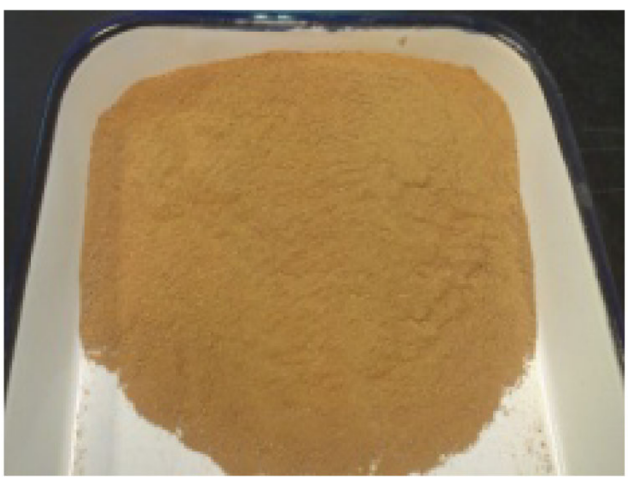

Fig. 13 Loess materials used in the field test (a) and laboratory test (b)

\section{Conclusions}

A full-scale testing facility of an inclined CBC, consisting of a compacted loess layer underlain by a gravel layer, was constructed at the Xi'an landfill. Tests were performed before and after planting vegetation on the cover to measure the gas permeability of the compacted loess. The following conclusions can be drawn from interpretation of the experimental results.

1. The gas permeability of the compacted loess $\left(\rho_{\mathrm{d}}=1.45 \mathrm{Mg} / \mathrm{m}^{3}\right)$ slightly reduced when volumetric water content increased from the average field capacity (i.e., $32 \%$ ) to $85 \%$ saturation (i.e., $40 \%$ ). However, when the saturation was greater than $85 \%$, the gas permeability significantly decreased with a further increment in volumetric water content. A capillary break at the interface between the compacted loess layer and the gravel layer allows the upper loess layer to retain more water, and conversely decreases its gas permeability, which is favorable for the CBC with respect to reducing landfill gas emissions.

2. Before planting vegetation, for the compacted loess $\left(\rho_{\mathrm{d}}=1.45 \mathrm{Mg} / \mathrm{m}^{3}\right)$, the field measurements of gas permeability ranged from $3.67 \times 10^{-12}$ to $5.73 \times 10^{-14} \mathrm{~m}^{2}$ when the volumetric water content changed from $36 \%$ to $46 \%$; for the compacted loess $\left(\rho_{\mathrm{d}}=1.3 \mathrm{Mg} / \mathrm{m}^{3}\right)$, the gas permeability ranged from $1.41 \times 10^{-11}$ to $2.25 \times 10^{-12} \mathrm{~m}^{2}$ when the volumetric water content changed from $26 \%$ to $29 \%$. After planting vegetation, the field measurement of the gas permeability of the compacted loess $\left(\rho_{\mathrm{d}}=1.45 \mathrm{Mg} / \mathrm{m}^{3}\right)$ was one order of magnitude lower than before planting vegetation. The growth of vegetation roots tends to fill the large pores in the compacted loess.

3. The field measurements of gas permeability of the compacted loess were about one to two orders of magnitude greater than the laboratory measurements. This is because the loess material used in the field test contained large soil clods, which resulted in an increase in gas permeability due to an increase in pore size and a decrease in tortuosity.

\section{References}

Albright, W.H., Glendon, W.G., 2002. Alternative Cover Assessment Project (ACAP): Phase I Report. Desert Research Institute, USA.

Albright, W.H., Benson, C.H., Gee, G.W., et al., 2004. Field water balance of landfill final covers. Journal of Environmental Quality, 33(6):2317-2332. http://dx.doi.org/10.2134/jeq2004.2317

Bolen, M.M., Roesler, A.C., Benson, C.H., et al., 2001. Alternative Cover Assessment Program: Phase II Report. Geo-Engineering Report.

Benson, C.H., Bohnhoff, G.L., Ogorzalek, A.S., et al., 2005. Field data and model predictions for a monolithic 
alternative cover. Geo-Frontiers Congress 2005, Austin, Texas, USA, p.1-16. http://dx.doi.org/10.1061/40789(168)29

Hamamoto, S., Moldrup, P., Kawamoto, K., et al., 2011. Extreme compaction effects on gas transport parameters and estimated climate gas exchange for a landfill final cover soil. Journal of Geotechnical and Geoenvironmental Engineering, 137(7):653-662.

http://dx.doi.org/10.1061/(ASCE)GT.1943-5606.0000459

Jucá, J.F.T., Maciel, F.J., 2006. Gas permeability of a compacted soil used in a landfill cover layer. Unsaturated Soils 2006, p.1535-1546.

http://dx.doi.org/10.1061/40802(189)128

Khire, M.V., Benson, C.H., Bosscher, P.J., 1997. Water balance modeling of earthen final covers. Journal of $\mathrm{Ge}$ otechnical and Geoenvironmental Engineering, 123(8): 744-754.

http://dx.doi.org/10.1061/(ASCE)1090-0241(1997)123:8 (744)

Kozlowski, T.T., 1999. Soil compaction and growth of woody plants. Scandinavian Journal of Forest Research, 14(6): 596-619. http://dx.doi.org/10.1080/02827589908540825

Liu, F.Y., Zhang, Z., Zhou, D., 2010. Density-saturationdependent air-water permeability function of unsaturated loess. Chinese Journal of Rock Mechanics and Engineering, 29(9): 1907-1914 (in Chinese).

Mcguire, P.E., Andraski, B.J., Archibald, R.E., 2009. Case study of a full-scale evapotranspiration cover. Journal of Geotechnical and Geoenvironmental Engineering, 135(3):316-332.

http://dx.doi.org/10.1061/(ASCE)1090-0241(2009)135:3 (316)

Maciel, F.J., Jucá, J.F.T., 2000. Laboratory and field test for studying gas flow through MSW landfill cover soil. ASCE GeoDenver 2000, Advances in Unsaturated Geotechnics, p.569-585. http://dx.doi.org/10.1061/40510(287)38

Moldrup, P., Olesen, T., Komatsu, T., et al., 2001. Tortuosity, diffusivity, and permeability in the soil liquid and gaseous phases. Soil Science Society of America Journal, 65(3): 613-623.

http://dx.doi.org/10.2136/sssaj2001.653613x

Ng, C.W.W., Liu, J., Chen, R., 2015. Numerical investigation on gas emission from three landfill soil covers under dry weather conditions. Vadose Zone Journal, 14(8):1-10. http://dx.doi.org/10.2136/vzj2014.12.0180

Pierret, A., Moran, C.J., Pankhurst, C.E., 1999. Differentiation of soil properties related to the spatial association of wheat roots and soil macropores. Plant and Soil, 211(1): 51-58.

http://dx.doi.org/10.1023/A:1004490800536

Stewart, J.B., Moran, C.J., Wood, J.T., 1999. Macropore sheath: quantification of plant root and soil macropore association. Plant and Soil, 211(1):59-67. http://dx.doi.org/10.1023/A:1004405422847

Scanlon, B.R., Reedy, R.C., Keese, K.E., et al., 2005. Evaluation of evapotranspirative covers for waste containment in arid and semiarid regions in the southwestern USA. $\mathrm{Va}$ dose Zone Journal, 4(1):55-71.

http://dx.doi.org/10.2113/4.1.55

Wang, Y.C., Li, G.Z., Li, D.Y., 2003. The measurement of the gas viscosity factor. Physics and Engineering, 13(2): 37-40 (in Chinese).

Wickramarachchi, P., Kawamotoa, K., Hamamotoa, S., et al., 2011. Effects of dry bulk density and particle size fraction on gas transport parameters in variably saturated landfill cover soil. Waste Management, 31(12):2464-2472. http://dx.doi.org/10.1016/j.wasman.2011.07.008

Yao, Z.H., Chen, Z.H., Huang, X.F., et al., 2012. Experimental research on gas permeability of unsaturated Q3 loess. Chinese Journal of Rock Mechanics and Engineering, 31(6): 1264-1273 (in Chinese).

Zhan, L.T., Jia, G.W., Deng, L.H., et al., 2012. Performance of earthen final covers of landfills in humid areas. Chinese Journal of Geotechnical Engineering, 34(10):1812-1818 (in Chinese).

Zhan, L.T., Yang, Y.B., Chen, R., et al., 2014. Influence of clod size and volumetric water content on gas permeability of a compacted loess. Canadian Geotechnical Journal, 51(12):1468-1474. http://dx.doi.org/10.1139/cgj-2014-0126

Zhan, T.L., 2015. Moisture and gas flow properties of compacted loess final covers for MSW landfills in Northwest China. 6th Asian-Pacific Region Conference of Unsaturated Soil Mechanics, Guilin, China.

Zhan, T.L., Ng, C.W.W., Fredlund, D.G., 2007. Field study of rainfall infiltration into a grassed unsaturated expansive soil slope. Canadian Geotechnical Journal, 44(4): 392-408. http://dx.doi.org/10.1139/t07-001

Zhang, W.J., Qiu, Z.H., Zhou, C.R., et al., 2009. Evaluation of evapotranspiration covers of landfills in Yangtze River delta region. Chinese Journal of Geotechnical Engineering, 31(3):384-389 (in Chinese).

\section{中文概要}

题 目: 现场测试固废填埋场压实黄土覆盖层的气相渗透 系数

目 的: 我国西北地区黄土分布广泛, 黄土作为当地固废 填埋场的覆盖土料具有广泛的应用前景。现场尺 度测试压实黄土覆盖层的气相渗透系数, 从而可 用于评估其填埋气减排性能。

方 法：1. 在西安固废填埋场建立压实黄土覆盖层试验基 
地（图 2); 2. 在试验基地的膜内核心测试区域布 置通气试验系统, 包括空气压缩机、通气管网、 气压测试装置、含水率测试装置、温度传感器和 静态箱 (图 3，5 7); 3. 在覆盖层表面裸露时和 植草后分别进行通气试验测试压实黄土覆盖层 的气相渗透系数。

结 论：1. 当饱和度低于 $85 \%$ 时, 干密度为 $1.45 \mathrm{Mg} / \mathrm{m}^{3}$ 压实黄土的气相渗透系数随含水率增加而降低, 但并不明显; 但是当饱和度高于 $85 \%$ 时, 气相渗 透系数随含水率增加而显著减小; 2. 黄土层和碎 石层之间的毛细阻滞作用使得上部黄土层储存 更多水分, 并显著降低其气相渗透系数, 这有利
于降低填埋气的排放; 3. 裸露条件下, 当压实黄 土的体积含水率从 $36 \%$ 增加至 46\%时, 其气相渗 透系数从 $3.67 \times 10^{-12} \mathrm{~m}^{2}$ 降低至 $5.73 \times 10^{-14} \mathrm{~m}^{2}$; 4. 植草后压实黄土的气相渗透系数比裸露条件 下小近一个数量级, 这主要是因为植被根系占据 了压实黄土的大孔隙； 5 . 现场尺度的压实黄土气 相渗透系数比室内试验的结果高 1 至 2 个数量 级, 这主要是因为现场所用黄土含有大的结团, 结团会增加黄土的孔隙直径以及减小孔隙的曲 折度。

关键词: 压实黄土; 毛细阻滞型覆盖层; 气相渗透系数; 体积含水率; 填埋场 